\title{
Preliminary estimates of mass-loss rates, changes in stable isotope composition, and invertebrate colonisation of evergreen and deciduous leaves in a Waikato, New Zealand, stream
}

\section{BRENDAN J. HICKS}

\section{J. LEE LABOYRIE}

Department of Biological Sciences

University of Waikato

Private Bag 3105

Hamilton, New Zealand

\begin{abstract}
Rates of mass loss are important in the choice of tree species used in riparian rehabilitation because leaves that break down fast should contribute to stream food-webs more rapidly than leaves that break down more slowly. To examine comparative mass-loss rates of some native evergreen and introduced deciduous trees in a New Zealand stream, fallen leaves were incubated in bags with $2 \times 3 \mathrm{~mm}$ mesh openings. The native trees were mahoe (Melicytus ramiflorus), kahikatea (Dacrycarpus dacrydioides), silver beech (Nothofagus menziesii), rewarewa (Knightia excelsa), tawa (Beilschmiedia tawa), and the introduced trees were silver birch (Betula pendula) and alder (Alnus glutinosa). The leaf bags were left in the Mangaotama Stream for 28 days from mid April to mid May 1995 when mean water temperature was $14.5^{\circ} \mathrm{C}$, giving a total of 406 degree days. Rates of mass loss followed the sequence: mahoe $>$ silver birch $>$ alder $>$ kahikatea $>$ silver beech $>$ rewarewa $>$ tawa. Mean mass-loss rate for mahoe, assuming a negative exponential model, was $\left.0.0507 \mathrm{kday}^{-1}(0.00350 \mathrm{k} \text { (degree day })^{-1}\right)$, and for tawa was $0.0036 \mathrm{kday}^{-1}(0.00025 k$ (degree day $\left.)^{-1}\right) . \mathrm{C}: \mathrm{N}$ ratio decreased on average from $45: 1$ to $35: 1$, and $\delta^{15} \mathrm{~N}$ increased between 0.7 and $3.0 \%$ ( $1.8 \pm 0.41 \%$, mean \pm 1 standard error), excluding kahikatea. Changes in $\delta^{13} \mathrm{C}$ were smaller and not consistent in direction. Biomass of invertebrates was greatest in bags that had lost $25-45 \%$ of their initial leaf biomass.
\end{abstract}

\section{M98029}

Received II June 1998; accepted 10 December 1998
Keywords mass loss; leaf litter; invertebrate colonisation; carbon; nitrogen; stable isotopes

\section{INTRODUCTION}

Fallen leaves can provide a major energy source for forest stream ecosystems, but decomposition, or "conditioning" by microbial colonisation is generally necessary to lower the $C: N$ ratio, and thereby increase the food value of leaves to aquatic invertebrates (Cummins et al. 1989). In riparian restoration, trees are often the obvious choice of vegetation because they provide shade and bank stability in addition to energy supply from allochthonous inputs. However, the final choice of tree species may depend on litter fall patterns and the nutritive value of the leaves. Many trees that have been introduced to New Zealand riparian zones are deciduous with a pulsed autumnal litter fall, e.g., willows (Salix spp.), alder (Alnus spp.), and poplars (Populus spp.). In contrast, most New Zealand native trees are evergreen with broader seasonal pulses of litter fall (Miller 1963; Cowan et al. 1985; Sweetapple \& Fraser 1992). The poorly synchronised and flexible life histories of New Zealand stream invertebrates suggest that they are not adapted to tightly pulsed litter inputs (Winterbourn et al. 1981).

Abscised leaves generally have a high $\mathrm{C}: \mathrm{N}$ ratio, which makes them a poor food source. Leaf decomposition in streams can be divided into three phases (Boulton \& Boon 1991). First, during the leaching phase the labile and soluble components that are easily broken down or dissolved are rapidly lost to the water column. Rapid weight loss of 5-27\% can occur in $24 \mathrm{~h}$ as soluble matter is leached into the stream (Petersen \& Cummins 1974). Second, during the conditioning phase microbes (mostly bacteria, hyphomycete fungi, and actinomycetes) colonise the wetted leaves, reducing the $\mathrm{C}: \mathrm{N}$ ratio by decreasing the $\mathrm{C}$ content and increasing the $\mathrm{N}$ content. Aquatic hyphomycetes are important agents in leaf breakdown in New Zealand streams (Aimer 1989). To some extent these two phases may be an artefact 
of drying leaves before stream incubation, as in one study a distinct leaching phase was not observed in fresh litter (Gessner 1991). Fresh leaves are subject to slower leaching than dried leaves, but may still exhibit a considerable range of leaching rates $(6-$ $18 \%$ in 2 weeks; France et al. 1997). Third, mechanical breakdown of leaves weakened by conditioning can occur by the actions of invertebrates or by physical abrasion (Boulton \& Boon 1991).

During conditioning in laboratory streams at $15^{\circ} \mathrm{C}$, air-dried leaves of red maple (Acer rubrum), dogwood (Cornus florida), and white oak (Quercus alba) lost 22-34\% of their mass in 28 days because of microbial activity alone (Mulholland et al. 1984). Conditioning increases the nutrient content of the leaf detritus because microbes use nitrate and phosphate from the water, and $\mathrm{C}$ from the leaf, to build their own proteins. Fungi can be particularly important to the conditioning process (Griffith \& Perry 1994; Baldy et al. 1995).

Parallel with the reduction of $\mathrm{C}: \mathrm{N}$ ratio by decomposition, we would expect to see predictable changes in the ratios of stable isotopes of carbon and nitrogen in the leaf litter after incubation. Each consumption step in a food-web, including microbial decomposition, generally increases the $\delta^{13} \mathrm{C}$ by c. 0 $1 \%$, and the $\delta^{15} \mathrm{~N}$ by c. $3 \%$, between the source and the consumer. This is because diffusion and enzymatic processes discriminate against the heavier isotopes (Peterson \& Fry 1987). Knowledge of the isotopic changes that occur in litter decomposition is necessary for the interpretation of stream foodwebs through stable isotope studies.

Physical breakdown occurs as the third phase, in which invertebrates and mechanical disruption degrade the physical structure of the leaves. Mechanical breakdown following conditioning has been largely attributed to the functional feeding group known as shredders, which typically comprise species of large, cased caddisfly larvae, and stonefly and cranefly larvae (Murphy \& Meehan 1991). Mass loss can be attributed to all three phases. However, it has been argued that New Zealand streams are typically poor in recognised shredders (Winterbourn et al. 1981).

A common method that has been used to investigate leaf decomposition and breakdown is to incubate preweighed leaves in mesh bags that are immersed in a stream. Other approaches are to tether leaves in-stream, or to bind leaves to immovable instream surfaces (Boulton \& Boon 1991). In their extensive review of studies of leaf decomposition, Boulton \& Boon criticised experiments that investigate breakdown rates using leaves contained in mesh bags because of artefacts that may be introduced, such as exclusion of macro-invertebrates, and anoxic conditions in the centre of the leaf mass. However, we consider that incubation of leaves in mesh bags is a useful first approximation of comparative breakdown rates, and one that avoids overestimation of mass-loss rates by loss of large particles that have not been totally decomposed (e.g., Petersen \& Cummins 1974). As the three phases of decomposition were not been separated in our study, we have investigated mass loss rather than the specific decay processes. The objectives of this paper were to: (1) compare rates of mass loss between leaves of some deciduous and evergreen tree species; (2) determine changes in $\mathrm{C}$ and $\mathrm{N}$ content and ratios of stable isotopes during the conditioning process; and (3) make preliminary estimates of invertebrate colonisation.

\section{METHODS}

The Mangaotama Stream at the study site (map reference S14 26953 63797, Department of Lands and Survey 1979) drains a catchment of $18.9 \mathrm{~km}^{2}$. The stream at this point is deeply entrenched, and meanders through pasture with scattered patches of kanuka (Kunzea ericoides), barberry (Berberis glaucocarpa), and blackberry (Rubus fruticosus agg.). Stream gradient was $0.0015 \mathrm{~m} \mathrm{~m}^{-1}$, and mean surface water width was $3.53 \mathrm{~m}$ (standard deviation $0.76, N=10$, NIWA unpubl. data). The substrate at the site was visually estimated to be $60 \%$ very fine gravel $(2-4 \mathrm{~mm})$ and $40 \%$ fine gravel $(4-8 \mathrm{~mm}$ ).

Abscised leaves were collected from the native evergreens-mahoe (Melicytus ramiflorus), kahikatea (Dacrycarpus dacrydioides), silver beech (Nothofagus menziesii), rewarewa (Knightia excelsa), and tawa (Beilschmiedia tawa), and the introduced, deciduous trees-silver birch (Betula pendula) and alder (Alnus glutinosa). Leaves were generally dry and lacked coloration from chlorophyll pigments, with the exception of mahoe leaves, which were freshly fallen, and still green.

Leaves were oven-dried to a constant weight at $40^{\circ} \mathrm{C}$ for $24 \mathrm{~h}$. Following drying, leaves were cooled and weighed before packing into mesh bags $130 \mathrm{~mm}$ $\times 220 \mathrm{~mm}$. Mesh openings were oval, $2 \times 3 \mathrm{~mm}$, allowing access for small invertebrates. Because of the variations in leaf size, similar volumes of leaf material had different weights for different species. A known weight of between 6 and $16 \mathrm{~g}$ of leaf 
material, depending on species, was loosely packed into each bag. Three replicate bags were made for each species, except for silver birch, for which there were only two.

On 18 April 1995, the leaf-filled mesh bags were suspended on a wire strung between two 1-m long steel spikes. These spikes were placed $2.6 \mathrm{~m}$ apart, and were driven vertically into the bed of the Mangaotama Stream at the tail of a pool. Leaf bags with different species were threaded randomly along the wire, which was perpendicular to the stream flow, and $\mathrm{c} .1 \mathrm{~cm}$ above the streambed. Each time that stream temperature was measured after the start of incubation, the bags were given a gentle shake to free them from the light covering of gravel that had accumulated on them.

The water width at the incubation transect was $4.50 \mathrm{~m}$, and mean water depth at five equally spaced intervals across the stream was $0.14 \mathrm{~m}$ (standard error (SE) $0.021 \mathrm{~m}$ ). On 21 April the mean water column velocity ranged from 0.17 to $0.42 \mathrm{~m} \mathrm{~s}^{-1}$ (mean 0.30, SE 0.032, $N=8$ ), and stream discharge was 199 litres $\mathrm{s}^{-1}$. Stream temperature was measured at the start of incubation, twice during incubation (21 April and 7 May), and again upon removal of the bags after 28 days ( 15 May). Water temperature was measured at c. $1000 \mathrm{~h}$ ranged from 11 to $16^{\circ} \mathrm{C}$ (mean 14.5 , SE $1.2, N=4$ ). The calculated number of degree days for the incubation period was 406 .

After removal, the mesh bags were placed in separate ziplock plastic bags, transported on ice to the laboratory, and frozen before processing. After thawing, leaves and leaf fragments were gently washed free of accumulated sediment, and invertebrates were separated from them, identified to order and family, and counted. Both leaves and invertebrates were oven-dried at $40^{\circ} \mathrm{C}$ before cooling and weighing.

\section{Mass-loss model}

Leaf mass loss over time was assumed to follow a negative exponential breakdown model (e.g., Petersen \& Cummins 1974; Linklater 1995):

$$
W_{t}=W_{0} e^{-k t}
$$

where $W_{0}$ is leaf dry weight at time $0, W_{t}$ is the leaf dry weight at time $t$, and $t$ is time in days. The coefficient of mass loss $(k)$, expressed in days, was calculated as:

$$
k=\frac{\ln \left(W_{0}\right)-\ln \left(W_{t}\right)}{t}
$$

Time to $50 \%$ mass loss $\left(t_{50}\right)$ was calculated from the negative exponential mass-loss model. Mass-loss rates were also expressed as $k$ (degree day) ${ }^{-1}$, and as the degree days required for $50 \%$ mass loss $\left(\mathrm{DD}_{50}\right)$, where degree days is the mean water temperature times the number of days of incubation. The mass-loss coefficient based on degree days was assumed to follow an negative exponential model, in which degree days were substituted for $t$ in Equations 1 and 2 above.

Both $\mathrm{C}$ and $\mathrm{N}$ content of leaves, and $\delta^{13} \mathrm{C}$ and $\delta^{15} \mathrm{~N}$ values, were measured before and after incubation in the stream. Elemental content was determined with a Carlo-Erba gas chromatograph, and $\delta^{13} \mathrm{C}$ and $\delta^{15} \mathrm{~N}$ values were determined with a Europa Tracermass mass spectrometer to a precision of $0.1 \%$ for $\delta^{13} \mathrm{C}$ and $0.3 \%$ for $\delta^{15} \mathrm{~N}$ (Hicks 1997 ). Because of limited resources, stable isotope analyses were restricted to one determination per tree species before and after incubation.

Correlations among rates of mass loss, $\mathrm{C}$ and $\mathrm{N}$ composition, changes in $\delta^{13} \mathrm{C}$ and $\delta^{15} \mathrm{~N}$ with incubation were determined with SYSTAT 7.0. As the correlation matrix was not positive definite, the individual Bonferroni probabilities were suspect (Wilkinson 1997). As an alternative, we used the rule of thumb in which large correlations were defined as those with $|r|>0.7$. This alternative is appropriate for preliminary analyses (Chatfield \& Collins 1980 ), such as the present study.

\section{RESULTS}

\section{Leaf mass loss}

Rates of mass loss in the leaf bags followed the sequence: mahoe $>$ silver birch $>$ alder $>$ kahikatea $>$ silver beech $>$ rewarewa $>$ tawa (Table 1, Appendix 1). For mahoe, $74 \%$ of the original weight was lost after 28 days, compared to only $10 \%$ for tawa. The mahoe leaves had been skeletonised, whereas the tawa leaves were still whole. Silver birch and mahoe lost mass relatively quickly (mean $k$ day $^{-1}=0.0325-$ 0.0507: Fig. 1, Table 1), whereas rewarewa and tawa lost mass relatively slowly (mean $k$ day $^{-1}=0.0036$ $0.0045)$. Mass-loss rates for silver beech, kahikatea, and alder were intermediate $\left(k\right.$ day $^{-1}=0.0103$ $0.0216)$. The time taken for $50 \%$ mass loss $\left(t_{50}\right)$, assuming a negative exponential model, was inversely proportional to the $k$ day $^{-1}$, and ranged from 15 days for mahoe to 196 days for tawa (Table 1). In degree days, mass-loss coefficients ranged from 0.00025 for tawa to $0.00350 k$ (degree day) ${ }^{-1}$ for 


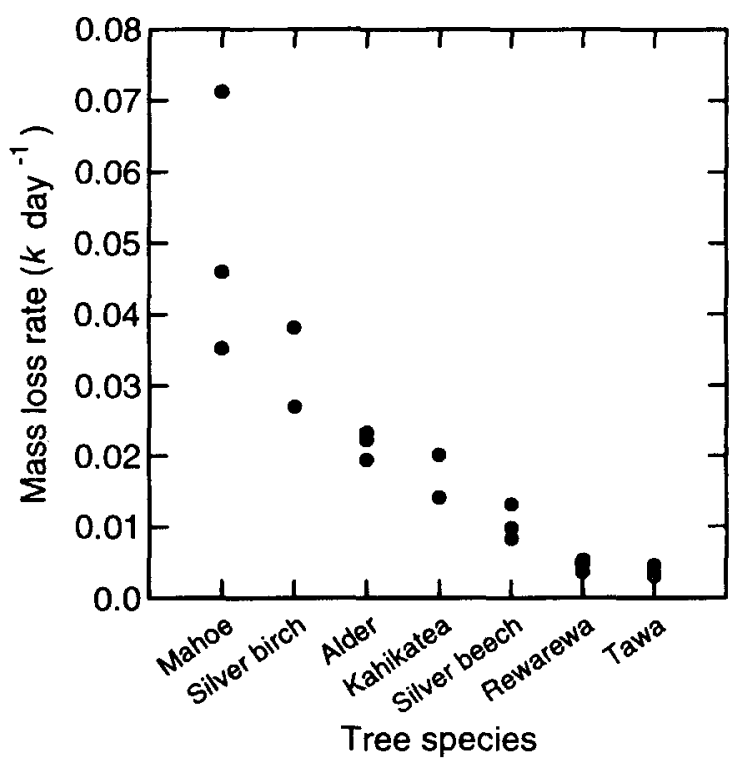

Fig. 1 Mass-loss rates for leaves of native and introduced tree species incubated for 28 days at a mean temperature of $14.5^{\circ} \mathrm{C}$ in the Mangaotama Stream, Waikato, New Zealand. (Mahoe (Melicytus ramiflorus); silver birch (Betula pendula); alder (Almus glutinosa); kahikatea (Dacrycarpus dacrydioides); silver beech (Nothofagus menziesii); rewarewa (Knightia excelsa); tawa (Beilschmiedia tawa); $N=3$ except for silver birch, where $N=2$.) mahoe. $\mathrm{DD}_{50}$ ranged from 215 (mahoe) to 2836 (tawa). Means of percent mass loss per degree day, calculated assuming a linear model of weight loss, ranged between 0.024 and $0.182 \%$ per degree day (Table 1).

\section{Carbon and nitrogen dynamics}

$C: N$ ratio decreased on average from $45: 1$ to $35: 1$ with incubation for 28 days (Table $2 \mathrm{~A}$ ). Before incubation, $\mathrm{C}: \mathrm{N}$ ratio was lowest in mahoe and alder (23:1 to $20: 1$ ), and was greatest in rewarewa (89:1; Table 2A). After incubation, the $\mathrm{C}: \mathrm{N}$ ratio declined in all species except for the skeletonised mahoe. The C:N ratio of silver birch declined by $50 \%$ from $47: 1$ to $23: 1$, whereas kahikatea fell only $11 \%$ from $66: 1$ to $59: 1$. The $\mathrm{C}: \mathrm{N}$ ratio of mahoe increased from $23: 1$ to $30: 1$ with incubation. The decreases in $\mathrm{C}: \mathrm{N}$ ratios were primarily attributable to increases in $\mathrm{N}$ content, as $\mathrm{C}$ content as a percentage changed relatively little (Table 2A).

$\delta^{13} \mathrm{C}$ values before incubation were typical of $\mathrm{C}_{3}$ plants, ranging from -28.7 to $-32.0 \%$ (Table $2 \mathrm{~B}$ ). After incubation, $\delta^{13} \mathrm{C}$ changed little, except in mahoe, which decreased by $1.4 \%$. $\delta^{15} \mathrm{~N}$ values before incubation were proportionally more variable than $\delta^{13} \mathrm{C}$ values, ranging from $-2.9 \%$ for tawa to $2.5 \%$ for kahikatea. After incubation, $\delta^{15} \mathrm{~N}$ increased

Table 1 Mean mass-loss rates for leaves incubated in mesh bags in the Mangaotama Stream, Waikato, New Zealand. Standard errors in parentheses.

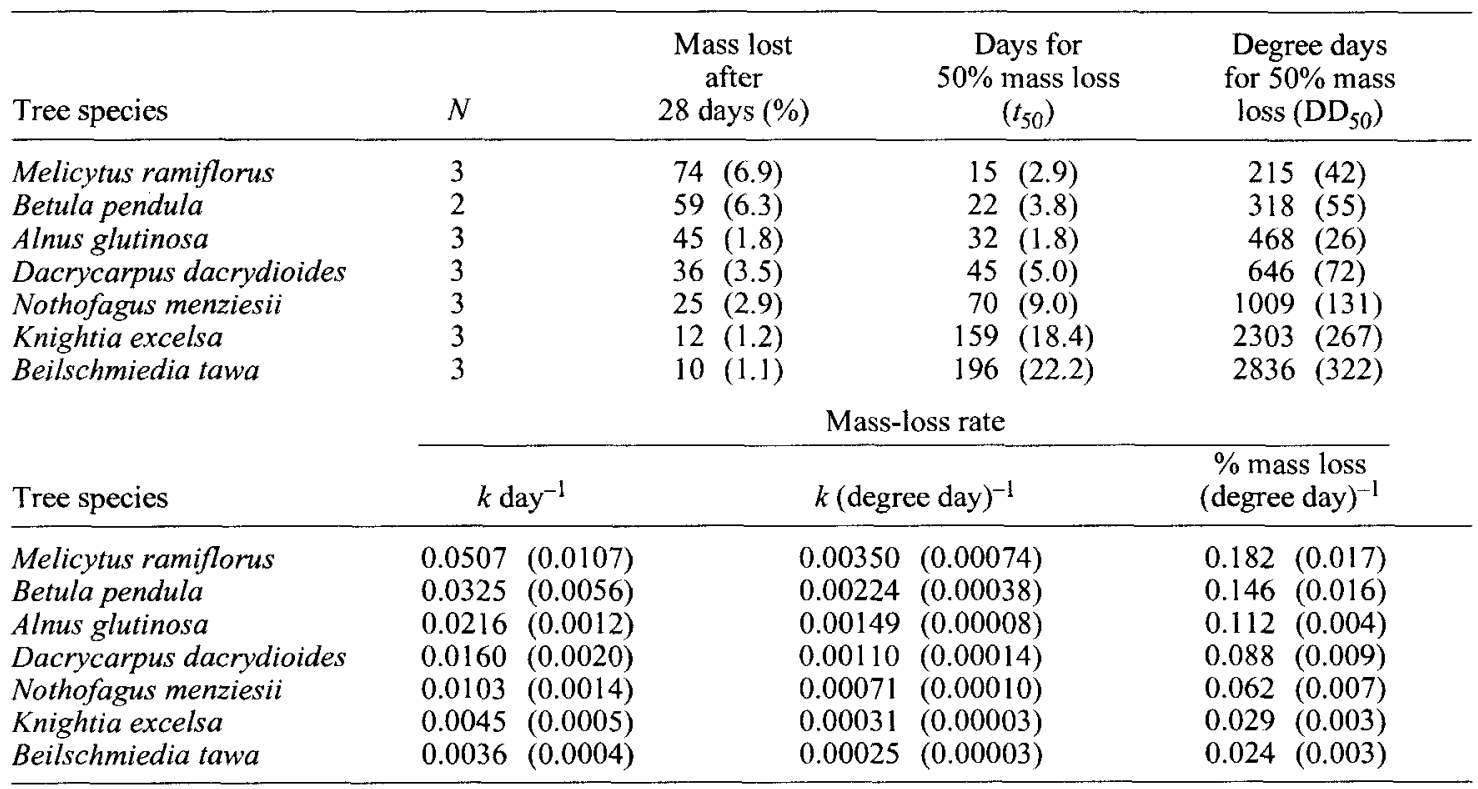


between 0.7 and $3.0 \%$ for all species except kahikatea, which fell by $1.3 \%$. The fall in $\delta^{15} \mathrm{~N}$ in kahikatea may have been caused by the loss of fine, needle-like leaflets from the leaf bags, as the leaflets were smaller than the mesh size. As a consequence the more lignified woody twigs were preferentially retained in the bags.

Correlation analysis showed a positive association (with $|r|>0.7$ ) between mean rates of mass loss $\left(k\right.$ day $\left.^{-1}\right)$ and the number of invertebrates $\mathrm{g}^{-1}$ of leaf material remaining after incubation (Table 3), indicating that leaves with the fastest rates of mass loss also had the greatest invertebrate abundance. Invertebrate abundance was negatively correlated with decrease in $\mathrm{C}: \mathrm{N}$ ratio and the change in $\delta^{13} \mathrm{C}$ with incubation. Leaves with the highest $\mathrm{C}$ content before incubation also tended show the greatest increase in $\mathrm{C}: \mathrm{N}$ ratio with incubation, and also to be the most ${ }^{13} \mathrm{C}$-enriched. The increase of $\delta^{13} \mathrm{C}$ with incubation was correlated with $\mathrm{C}: \mathrm{N}$ ratio before incubation, and decrease in $\mathrm{C}: \mathrm{N}$ ratio with incubation. A strong negative association between $\mathrm{N}$ content and $\mathrm{C}: \mathrm{N}$ ratio before incubation $(r=-0.90$; not shown in Table 3$)$ was expected because $\mathrm{N}$ content was quite variable among species, whereas $\mathrm{C}$ content varied little.

\section{Invertebrate colonisation}

Numbers of invertebrates per leaf bag after incubation ranged from 76 to 314 per bag $(124 \pm 26.6$, mean $\pm 95 \%$ confidence interval; $N=20$ ), and were not different among the tree species (ANOVA, $F_{6,13}=$ $1.25, P=0.342$ ). In relation to the amount of leaf material that remained, numbers of invertebrates after incubation ranged from 5.6 to 151 individuals $\mathrm{g}^{-1}$ leaf material $(29.9 \pm 14.9$, mean $\pm 95 \%$ confidence interval; $N=20$; Appendix 1), and was also not different among the tree species (ANOVA, $F_{6,13}$ $=2.48, P=0.080$ ). High mean numbers on mahoe $\left(79.6 \mathrm{mg} \mathrm{g}^{-1}\right.$; Table 4) were attributable to the small dry weight of leaves that remained. Weight of invertebrates after incubation ranged from 27.7 to 218.9 $\mathrm{mg}$ per leaf bag, and was not different among the tree species (ANOVA, $F_{6,13}=1.04, P=0.445$ ). However, invertebrate biomass per $g$ of leaf material remaining was different among tree species (ANOVA, $\left.F_{6,13}=3.878, P=0.019\right)$. Invertebrate biomass on

Table 2 A, Carbon $(\mathrm{C})$ and nitrogen $(\mathrm{N})$ content; and $\mathrm{B}, \delta^{13} \mathrm{C}$ and $\delta^{15} \mathrm{~N}$ values, of leaves of native and introduced trees before and after incubation for 28 days in the Mangaotama Stream, Waikato, New Zealand. One determination per species and treatment.

\section{A Carbon and nitrogen content}

\begin{tabular}{|c|c|c|c|c|c|c|c|}
\hline \multirow[b]{2}{*}{ Tree species } & \multicolumn{2}{|c|}{ Percent $\mathrm{C}$} & \multicolumn{2}{|c|}{ Percent N } & \multicolumn{2}{|c|}{$\mathrm{C} / \mathrm{N}$} & \multirow{2}{*}{$\begin{array}{c}\text { Percent } \\
\text { decrease } \\
\text { in } \mathrm{C} / \mathrm{N}\end{array}$} \\
\hline & Before & $\overline{\text { After }}$ & Before & $\overline{\text { After }}$ & Before & $\overline{\text { After }}$ & \\
\hline Melicytus ramiflorus & 39.6 & 34.2 & 1.74 & 1.15 & 22.7 & 29.7 & -31 \\
\hline Betula pendula & 45.9 & 42.3 & 0.98 & 1.81 & 46.9 & 23.4 & 50 \\
\hline Alnus glutinosa & 47.5 & 41.1 & 2.34 & 2.61 & 20.3 & 15.8 & 22 \\
\hline Dacrycarpus dacrydioides & 44.3 & 44.0 & 0.67 & 0.75 & 66.1 & 58.7 & 11 \\
\hline Nothofagus menziesii & 49.3 & 46.5 & 1.38 & 1.63 & 35.7 & 28.5 & 20 \\
\hline Knightia excelsa & 45.3 & 47.2 & 0.51 & 0.83 & 88.8 & 56.9 & 36 \\
\hline Beilschmiedia tawa & 43.3 & 43.4 & 1.19 & 1.44 & 36.4 & 30.1 & 17 \\
\hline
\end{tabular}

$B \quad \delta^{13} \mathrm{C}$ and $\delta^{15} \mathrm{~N}$ values

\begin{tabular}{|c|c|c|c|c|c|c|}
\hline \multirow[b]{2}{*}{ Tree species } & \multicolumn{2}{|c|}{$\delta^{13} \mathrm{C}(\% \mathrm{o})$} & \multicolumn{2}{|c|}{$\delta^{15} \mathrm{~N}(\% 0)$} & \multicolumn{2}{|c|}{$\begin{array}{c}\text { Change with } \\
\text { incubation (\%o) }\end{array}$} \\
\hline & Before & $\overline{\text { After }}$ & Before & After & $\delta^{13} \mathrm{C}$ & $\delta^{15} \mathrm{~N}$ \\
\hline Melicytus ramiflorus & -32.0 & -33.4 & 1.0 & 2.6 & -1.4 & 1.6 \\
\hline Betula pendula & -28.7 & -28.4 & 2.5 & 5.5 & 0.2 & 3.0 \\
\hline Alnus glutinosa & -28.3 & -28.8 & -2.1 & -1.1 & -0.5 & 1.0 \\
\hline Dacrycarpus dacrydioides & -28.9 & -28.1 & 2.8 & 1.5 & 0.8 & -1.3 \\
\hline Nothofagus menziesii & -29.6 & -29.8 & 0.3 & 1.0 & -0.2 & 0.7 \\
\hline Knightia excelsa & -28.9 & -28.7 & -1.7 & 1.3 & 0.3 & 3.0 \\
\hline Beilschmiedia tawa & -31.1 & -31.3 & -2.9 & -1.5 & -0.2 & 1.4 \\
\hline
\end{tabular}


mahoe (mean $40.2 \mathrm{mg} \mathrm{g}^{-1}$ leaf material) was higher than kahikatea, rewarewa, or tawa $(P \leq 0.027$, Tukey's HSD multiple comparison; Table 4, Appendix 1).

We found a quadratic relationship between rates of mass loss and invertebrate biomass per leaf bag, indicating that leaves that had intermediate rates of mass loss harboured the greatest amount of invertebates (Fig. 2). For the equation:

$Y=-379-220 X-25.7 X^{2}$

where $Y=$ dry weight of invertebrates in $\mathrm{mg}$ per leaf bag, and $X=$ natural log of the rate of mass loss $(k$ day $\left.{ }^{-1}\right), r^{2}=0.64$. The tree species with the highest mean invertebrate biomasses (alder, kahikatea, and silver beech) had $t_{50}$ values of between 32 and 70 days, and had lost $25-45 \%$ of their initial leaf mass (Table 1).

Larval conoesucids (mainly Pycnocentria evecta and Olinga feredayi) were the most abundant invertebrates on the leaves of all tree species (Table 5). Mayfly nymphs (almost all of which were Leptophlebiidae) were the next most common. Coloburiscus humeralis was found only in silver-beech leaf

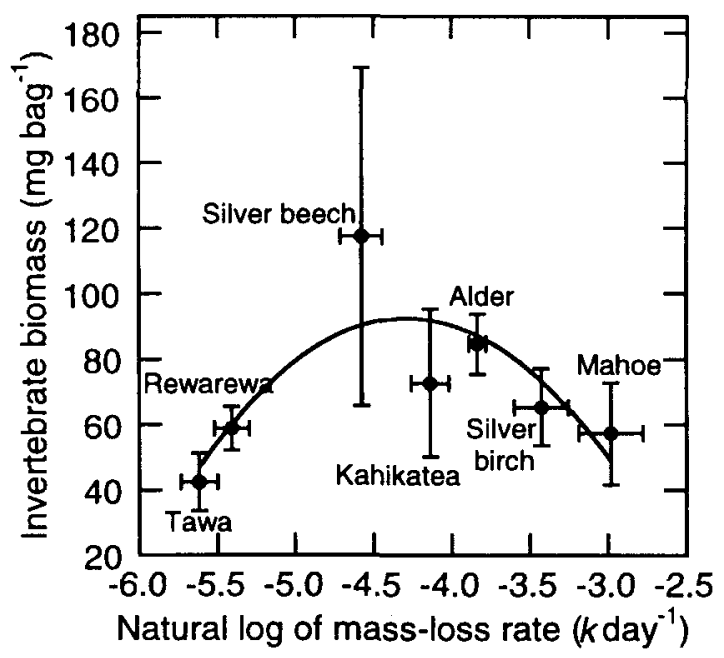

Fig. 2 Mean invertebrate abundance in leaf bags incubated for 28 days in the Mangaotama Stream, Waikato, New Zealand. (Alder (Alnus glutinosa); mahoe (Melicytus ramiflorus); kahikatea (Dacrycarpus dacrydioides); rewarewa (Knightia excelsa); silver beech (Nothofagus menziesii); silver birch (Betula pendula); tawa (Beilschmiedia tawa). $N=3$ except for silver birch, where $N=2$. Error bars represent one standard error.)

Table 3 Pearson correlations between carbon $(\mathrm{C})$ and nitrogen $(\mathrm{N})$ content of leaves, mean rates of mass loss, $\delta^{13} \mathrm{C}$ values, and number of invertebrates in leaf bags incubated in the Mangaotama Stream, Waikato, New Zealand. Correlations for which $|r|>0.7$ are shown in bold; $N=7$.

\begin{tabular}{|c|c|c|c|c|c|c|}
\hline Variable & 1 & 2 & 3 & 4 & 5 & 6 \\
\hline Mean rate of mass loss $\left(k\right.$ day $\left.^{-1}\right)$ & 1 & & & & & \\
\hline$\% \mathrm{C}$ before incubation & -0.52 & & & & & \\
\hline $\mathrm{C}: \mathrm{N}$ ratio before incubation & -0.49 & 0.07 & & & & \\
\hline$\%$ decrease in $\mathrm{C}: \mathrm{N}$ with incubation & -0.53 & 0.69 & 0.45 & & & \\
\hline$\delta^{13} \mathrm{C}$ before incubation & -0.35 & 0.76 & 0.39 & 0.77 & & \\
\hline Change in $\delta^{13} \mathrm{C}$ with incubation & -0.62 & 0.42 & 0.74 & 0.69 & 0.66 & \\
\hline No. of invertebrates $\mathrm{g}^{-1}$ leaf material after incubation 7 & 0.73 & -0.42 & -0.71 & -0.81 & -0.64 & -0.92 \\
\hline
\end{tabular}

Table 4 Mean invertebrate abundance on leaves in mesh bags at the end of incubation for 28 days in the Mangaotama Stream, Waikato, New Zealand. Leaf weights are dry weights; standard errors are given in parentheses.

\begin{tabular}{lccccc}
\hline & & \multicolumn{4}{c}{ Mean invertebrate abundance } \\
\cline { 3 - 6 } & $N$ & $\begin{array}{c}\text { No. of } \\
\text { invertebrates } \\
\text { per leaf bag }\end{array}$ & $\begin{array}{c}\text { No. of } \\
\text { invertebrates } \\
\mathrm{g}^{-1} \text { of leaves }\end{array}$ & $\begin{array}{c}\text { Weight (mg) of } \\
\text { invertebrates } \\
\text { per leaf bag }\end{array}$ & $\begin{array}{c}\text { Weight (mg) of } \\
\text { invertebrates } \\
\mathrm{g}^{-1} \text { of leaves }\end{array}$ \\
\hline Melicytus ramiflorus & 3 & $101(13)$ & $80(36)$ & $57(16)$ & $40(12.3)$ \\
Betula pendula & 2 & $98(6)$ & $19(1.6)$ & $65(12)$ & $13(4.0)$ \\
Alnus glutinosa & 3 & $155(26)$ & $36(4.2)$ & $85(9)$ & $20(1.3)$ \\
Dacrycarpus dacrydioides & 3 & $133(19)$ & $14(0.8)$ & $73(23)$ & $7(1.9)$ \\
Nothofagus menziesii & 3 & $184(66)$ & $30(11)$ & $118(52)$ & $19(8.7)$ \\
Knightia excelsa & 3 & $86(18)$ & $9(1.7)$ & $59(7)$ & $6(0.7)$ \\
Beilschmiedia tawa & 3 & $104(23)$ & $19(4.9)$ & $42(9)$ & $8(0.9)$ \\
\hline
\end{tabular}


bags. Elmids were uncommon on alder, silver beech, and tawa.

\section{DISCUSSION}

\section{Mass-loss rates}

Mass-loss rates spanned the range from "fast" (mahoe and silver birch, $>0.0015 k$ degree day" Table 1) to "slow" (silver beech, rewarewa, and tawa; $<0.0010 k$ degree day $^{-1}$ ) as defined by Cummins et al. (1989). Alder and kahikatea were intermediate $\left(0.0010-0.0015 k\right.$ degree day $\left.{ }^{-1}\right)$. Our mass-loss rates for mahoe (Table 6) were greater than previous estimates (Linklater 1991; Parkyn \& Winterbourn 1997), as were our estimates for tawa (Aimer 1989). Similarly, our mean for alder (Alnus glutinosa) was greater than for red alder in the United States (A. rubra; Sedell et al. 1975), but our massloss rate for silver beech was between estimates for red beech (Nothofagus fusca) and mountain beech (N. solandri var. cliffortoides; Parkyn \& Winterbourn 1997).

High water temperatures may account for the fast mass-loss rates recorded in our study, as some other studies have concluded that temperature is an important determinant of mass-loss rate (e.g., Hanson 1984; Webster \& Benfield 1986). For mahoe and alder, our faster rates coincided with higher incubation temperatures compared to those of other studies (Table 6). However, there has been some debate about the importance of temperature in determining mass-loss rate, and the relative importance of invertebrates and microbial processes (e.g., Irons et al. 1994). Relatively rapid mass-loss can occur near $0^{\circ} \mathrm{C}$ (e.g., Short et al. 1980). Also, the relatively fast velocity in which the leaf bags were held (mean water column velocity $0.30 \mathrm{~m} \mathrm{~s}^{-1}$ ) might have influenced the mass-loss rate. Despite these uncertainties we believe that our relatively high incubation temperature best accounts for our high rates of mass loss.

\section{Leaf conditioning}

The decrease in $\mathrm{C}: \mathrm{N}$ ratio that we measured (a mean of 10:1 across all tree species) represents a substantial improvement in food value for invertebrates. Other studies have shown decreases in $\mathrm{C}: \mathrm{N}$ ratios with leaf decomposition, e.g., in maple (Acer) species (Triska et al. 1975; Bird \& Kaushik 1992) and Douglas fir (Pseudotsuga menziesii; Triska et al. 1975). However, not all species show decreases; the $\mathrm{C}: \mathrm{N}$ ratio of red alder remained almost unchanged or increased (Triska et al. 1975). The initial C: $N$ ratio for alder in our study (20:1) was very similar to the initial C: $\mathrm{N}$ ratio for red alder in Oregon (c. 22:1Triska et al. 1975). In contrast to the Oregon study,

Table 5 Proportions of invertebrate taxa in leaf bags at the end of 28 days of incubation in the Mangaotama Stream, Waikato, New Zealand.

\begin{tabular}{lrrrrrrr}
\hline & \multicolumn{7}{c}{ No. of invertebrates as a percentage of the total } \\
\cline { 2 - 8 } Invertebrate taxon & $\begin{array}{c}\text { Melicytus } \\
\text { ramiflorus }\end{array}$ & $\begin{array}{c}\text { Betula } \\
\text { pendula }\end{array}$ & $\begin{array}{c}\text { Alnus } \\
\text { glutinosa }\end{array}$ & $\begin{array}{c}\text { Dacrycarpus } \\
\text { dacrydioides }\end{array}$ & $\begin{array}{c}\text { Nothofagus } \\
\text { menziesii }\end{array}$ & $\begin{array}{c}\text { Knightia } \\
\text { excelsa }\end{array}$ & $\begin{array}{c}\text { Beilschmiedia } \\
\text { tawa }\end{array}$ \\
\hline Ephemeroptera & & & & & & & \\
Leptophlebiidae & 22.6 & 28.3 & 29.3 & 41.7 & 15.6 & 40.6 & 31.2 \\
Coloburiscus & 0.0 & 0.0 & 0.0 & 0.0 & 0.6 & 0.0 & 0.0 \\
Total Ephemeroptera & 22.6 & 28.3 & 29.3 & 41.7 & 16.2 & 40.6 & 31.2 \\
Trichoptera & & & & & & & \\
Conoesucidae & 71.0 & 67.4 & 54.1 & 52.5 & 76.1 & 54.5 & 59.5 \\
Oeconesidae & 0.0 & 3.3 & 3.4 & 2.1 & 1.9 & 0.0 & 0.0 \\
Hydrobiosidae & 0.0 & 0.0 & 1.0 & 0.0 & 0.3 & 0.0 & 0.0 \\
Hydropsychidae & 3.2 & 0.0 & 0.0 & 0.0 & 0.0 & 0.6 & 0.0 \\
Total Trichoptera & 74.2 & 70.7 & 58.5 & 54.5 & 78.3 & 55.2 & 59.5 \\
Plecoptera & 0.0 & 0.0 & 0.5 & 1.7 & 0.3 & 1.2 & 0.8 \\
Coleoptera & 1.8 & 1.1 & 9.3 & 1.2 & 4.1 & 1.8 & 6.8 \\
Diptera & 0.9 & 0.0 & 2.4 & 0.8 & 0.6 & 1.2 & 1.7 \\
Mollusca & 0.5 & 0.0 & 0.0 & 0.0 & 0.3 & 0.0 & 0.0 \\
\hline
\end{tabular}


our $\mathrm{C}: \mathrm{N}$ ratio for alder decreased by $22 \%$. Initial $\mathrm{C}: \mathrm{N}$ ratios in our study were not significantly correlated with mass-loss rates.

Also associated with mass loss was an increase in $\delta^{15} \mathrm{~N}$ by $1.8 \pm 0.41 \%$ o (mean $\pm 1 \mathrm{SE}$, excluding kahikatea). This increase was probably caused by microbial colonisation, as trophic enrichment in $\delta^{15} \mathrm{~N}$ between a consumer and its $\mathrm{N}$ source is typically c. 3\%o (Peterson \& Fry 1987; Handley \& Raven 1992). At similar pasture stream sites, an increase in $\delta^{15} \mathrm{~N}$ of $2.3 \%$ occurred between trophic steps (Hicks 1997). Another source of ${ }^{15} \mathrm{~N}$ enrichment is $\mathrm{N}$ fixation, which can result in a variable increase in $\delta^{15} \mathrm{~N}$ of between 0.6 and $4.1 \%$ in the $\mathrm{N}$ fixers compared to their N source (Handley \& Raven 1992; France 1995).

Enrichment in ${ }^{13} \mathrm{C}$ was smaller and more variable than for ${ }^{15} \mathrm{~N}$, possibly reflecting the greater amount of $\mathrm{C}$ present initially. Also, different $\mathrm{C}$ pools within the leaf can have differing ${ }^{13} \mathrm{C}$ enrichment. For instance, lignin is typically depleted in ${ }^{13} \mathrm{C}$ (Benner et al. 1987), which may account for the relatively large depletion of $\delta^{13} \mathrm{C}$ in mahoe leaves when they were skeletonised.

\section{Invertebrate colonisation}

Our results suggest that invertebrate biomass reached a maximum in bags containing leaves of the tree species alder, kahikatea, and silver beech when 25 $45 \%$ of the leaf material had been lost (Table 1, Fig. 2). This is similar to the predictions of Cummins et al. (1989), that shredder biomass should be maximal when c. $50 \%$ of the leaf material remains. This usually occurs at between 300 and 600 degree days, depending on rate of breakdown of the leaf litter. Cummins et al. (1989) predicted that shredder biomass would be $60-80 \mathrm{mg} \mathrm{g}^{-1}$ dry weight of leaves for fast species, and $20-40 \mathrm{mg} \mathrm{g}^{-1}$ dry weight of leaves for slow species when $50 \%$ of the litter remained. We found considerably less invertebrate biomass than this; means ranged from 7.3 to $19.8 \mathrm{mg}$ $\mathrm{g}^{-1}$ for the species that seemed to have the greatest biomass of invertebrates per bag (alder, kahikatea, and silver birch). The high mean invertebrate biomass for mahoe was probably more a reflection of the low leaf weight remaining than the food value of the leaves after incubation. After 28 days invertebrate biomass was probably declining in mahoe and silver birch, but had yet to peak in rewarewa and tawa. We believe that the coarse taxonomic resolution that we used was appropriate to our study, as this level of resolution was sufficient to show invertebrate responses to gradients of physical conditions in Australian streams (Marchant et al. 1995).

Colonisation of mahoe in our study after 28 days (mean 80 individuals $\mathrm{g}^{-1}$ dry weight of leaf) was higher than colonisation of mahoe in the South Island of New Zealand after 100 days (about 50 individuals $\mathrm{g}^{-1}$ dry weight of leaf; Parkyn \& Winterbourn 1997). Weight of invertebrates $\mathrm{g}^{-1}$ dry weight of leaf material at the end of incubation (3.6$53 \mathrm{mg} \mathrm{g}^{-1}$ ) was similar to the invertebrate biomass $\left(0-50 \mathrm{mg} \mathrm{g}^{-1}\right)$ in leaf packs of vine maple (Acer circinatum), and the conifers Douglas fir and western hemlock ( $T$ suga heterophylla) in Oregon (Sedell et al. 1975). Maximum invertebrate numbers in Oregon (1-111 individuals $\mathrm{g}^{-1}$, were similar to our range (5.6-151 individuals $\mathrm{g}^{-1}$ ). Major differences

Table 6 Mass-loss rates compared between studies to the "fast" ( $k$ (degree day) $\left.{ }^{-1}>0.0015\right)$ and "slow" ( $k$ (degree day $)^{-1}<0.0010$ ) criteria of Cummins et al. (1989).

\begin{tabular}{|c|c|c|c|c|c|}
\hline \multirow[b]{2}{*}{ Tree species } & \multicolumn{2}{|c|}{ Mass-loss rate } & \multirow{2}{*}{$\begin{array}{c}\text { Temperature } \\
\left({ }^{\circ} \mathrm{C}\right)\end{array}$} & \multirow{2}{*}{$\begin{array}{l}\text { Relative speed } \\
\text { of mass loss }\end{array}$} & \multirow[b]{2}{*}{ Source } \\
\hline & $k{\text { (degree day })^{-1}}^{-1}$ & $k$ day $^{-1}$ & & & \\
\hline Melicytus ramiflorus & 0.00350 & 0.0507 & mean 14.5 & Fast & This study \\
\hline Melicytus ramiflorus & 0.00240 & 0.0274 & $5.5-14$ & Fast & Linklater (1991) \\
\hline Melicytus ramiflorus & & 0.0135 & c. $4-5$ & & Parkyn \& Winterbourn (1997) \\
\hline Alnus glutinosa & 0.00149 & 0.0216 & mean 14.5 & Intermediate & This study \\
\hline Nothofagus fusca & & $0.0124-0.0168$ & mean c. 8 & & Sedell et al. (1975) \\
\hline Nothofagus fusca & & 0.0225 & c. $4-5$ & & Parkyn \& Winterbourn (1997) \\
\hline Alnus rubra & 0.00170 & 0.0186 & $5.5-14$ & Fast & Linklater (1991) \\
\hline Nothofagus menziesii & 0.00071 & 0.0103 & mean 14.5 & Slow & This study \\
\hline N. solandri var, cliffortoides & & 0.0055 & c. $4-5$ & & Parkyn \& Winterbourn (1997) \\
\hline Beilschmiedia tawa & 0.00025 & 0.0036 & mean 14.5 & Slow & This study \\
\hline Beilschmiedia tawa & & $0.0025-0.0030$ * & $5-18$ & & Aimer (1989) \\
\hline
\end{tabular}

${ }^{\star}$ Calculated from leaves in mesh bags that lost $37 \%$ of their dry weight after $5-6$ months in a stream. 
between the two studies were the long incubation times in the Oregon study (from 180 to c. 300 days), and the lower water temperature (mean $8^{\circ} \mathrm{C}$ ). Also, leaves in the Oregon study were in packs and not confined in bags.

Leaves contained in mesh bags seem ideally suited to colonisation by shredders because of the stable environment they offer. New Zealand invertebrate communities are generally poor in shredders (Winterbourn et al. 1981) but part of the problem may be recognition of shredders. Conoesucid larvae made up $55-78 \%$ numerically of the invertebrate fauna, and Olinga feredayi and Pycnocentria evecta were the predominant conoesucids. These species have generally been classified as collector-browsers (e.g., Quinn et al. 1992), and O. feredayi can also act as a facultative shredder, possibly because of its collector-browser tendency to feed on a range of particle sizes (Winterbourn 1982; Quinn et al. 1992). $P$. forcipata, a congener of $P$. evecta, has been recognised as a shredder (Linklater \& Winterbourn 1993). Lester et al. (1994) recognised Olinga as shredders, but Pycnocentria as browsers.

In Canterbury, New Zealand, a stream flowing through mahoe-dominated forest had higher shredder production than streams flowing though tree fuchsia (Fuchsia excorticata) or red beech (Nothofagus fusca) forest (Linklater \& Winterbourn 1993). This may have been a consequence of the combination of higher benthic detritus in the mahoe stream (Linklater \& Winterbourn 1993) and the fast breakdown rates of mahoe (Linklater 1995), that were confirmed in our study.

\section{Applications and limitations}

All studies of breakdown rates contain experimental artefacts of one sort or another. With leaves contained in bags, there is a risk that the bags themselves might influence the mass-loss rates or colonisation by invertebrates. Containment in bags can slow breakdown (Webster \& Benfield 1986). Mesh bags can also change the water velocity around the leaves, trap sediment, and alter local chemical conditions (Boulton \& Boon 1991). However, not all leaf types can be readily tethered, so leaf bags seem a reasonable compromise when preliminary comparisons of breakdown rates for a wide range of species are made.

The size of material contained by or lost from mesh bags depends on the mesh size. We probably overestimated the relative speed of availability of kahikatea litter because an unknown amount of material escaped from the bags as the mesh size was too large to contain the finer fronds and leaflets. This loss of fine material may account for the reduction in $\delta^{15} \mathrm{~N}$ in kahikatea when all other species increased.

A practical application of these estimates of massloss rates and invertebrate colonisation is to evaluate the availability of leaf litter to the stream ecosystem. Plant species with leaves that lose mass fast might be considered better species for the riparian or streamside zone than species with slow breakdown rates, because species with fast rates of mass loss could be expected to release their energy to the stream ecosystem sooner. In our study, invertebrate biomass was correlated with speed of mass loss. Fast decay might be particularly important in larger streams, as retention of particulate organic matter decreases with increased stream size (Webster et al. 1994). The flashy and flood-prone nature of many New Zealand streams, as seen in the high coefficients of flow variation (Duncan 1992), may accentuate the problem of retention. On the other hand, colonisation of leaf material in our experiment showed that leaves that breakdown slowly can provide a substrate for invertebrates. Slow breakdown also allows time for leaves to be transported down stream where they might benefit invertebrates there. Thus a mix of tree species in the riparian zone seems wise.

The mixture of tree species can be used to address the timing and rates of leaf inputs to the stream ecosystem. The pulsed litter drop of deciduous trees such as alder may lower dissolved oxygen concentrations under dry conditions at the end of summer as leaves decay rapidly under low flow conditions (Hicks 1990). In New Zealand the predominantly evergreen trees do not exhibit a tightly pulsed autumnal litter fall, and most hardwood trees seem to have peak litter production in summer. Peak litter production by lowland podocarp-rata-broadleaf forest at Orongorongo on the south coast of the North Island was $30-50 \mathrm{~g} \mathrm{~m}^{-2}$ month $^{-1}$, and occurred from November to March, with less leaf drop (c. 10-20 g $\mathrm{m}^{-2}$ month $^{-1}$ ) from April to October (Daniel 1975). Kamahi (Weinmannia racemosa) had an autumnal maximum, and rimu (Dacrydium cupressinum) had litter fall maxima in spring and autumn (Cowan et al. 1985). Recent work suggests that a standing stock of $24 \mathrm{~g}$ dry weight $\mathrm{m}^{-2}$ of allochthonous material (the net result of input, retention, and decay) is required to offset the loss of gross primary production brought about by channel shading by riparian trees (J. M. Quinn, NIWA, Hamilton unpubl. data). Thus appropriate selection of New Zealand native evergreen trees could ensure relatively continuous litter inputs to a stream in spring, summer, and autumn, and a 
combination of tree species that have fast and slow mass-loss rates would ensure a continuous supply of allochthonous $\mathrm{C}$ for the stream community. An obvious extension of this preliminary work would be a wider survey of rates of mass loss in other woody and herbaceous species, and investigation of the incorporation of leaf biomass into stream food-webs.

\section{ACKNOWLEDGMENTS}

We thank John Quinn, NIWA, Hamilton, for help with experimental design and valuable comments on the manuscript. We acknowledge the help of the 0770.313 Freshwater Ecology class of 1995, especially Rachael Versloot, who sorted and weighed leaves after their decomposition. Kevin Collier, Jill Carter, and three anonymous referees also made suggestions for amendments to the manuscript.

\section{REFERENCES}

Aimer, R. D. 1989: Ecology of aquatic hyphomycetes in New Zealand streams. Unpublished PhD thesis, University of Waikato, Hamilton, New Zealand. $447 \mathrm{p}$.

Baldy, V.; Gessner, M. O.; Chauvet, E. 1995: Bacteria, fungi and breakdown of leaf litter in a large river. Oikos 74: 93-102.

Benner, R.; Fogel, M. L.; Sprague, E. K.; Hodson, R. E. 1987: Depletion of ${ }^{13} \mathrm{C}$ in lignin and its implications for carbon isotope studies. Nature 329: 708710 .

Bird, G. A.; Kaushik, N. K. 1992: Invertebrate colonization and processing of maple leaf litter in a forested and an agricultural reach of a stream. Hydrobiologia 234: 65-77.

Boulton, A. J.; Boon, P. I. 1991: A review of methodology used to measure leaf litter decomposition in lotic environments: time to turn over a new leaf? Australian Journal of Marine and Freshwater Research 42: 1-43.

Chatfield, C.; Collins, A. J. 1980: Introduction to multivariate analyses. London, Chapman and Hall.

Cowan, P. E.; Waddington, D. C.; Daniel, M. J.; Bell, B. D. 1985: Aspects of litter production in a New Zealand lowland podocarp/broadleaf forest. New Zealand Journal of Botany 23: 191-199.

Cummins, K. W.; Wilzbach, M. A.; Gates, D. M.; Perry, J. B.; Taliaferro, W. B. 1989: Shredders and riparian vegetation. Leaf litter that falls into streams influences communities of stream invertebrates. Bioscience 39: 24-30.
Daniel, M. J. 1975: Preliminary account of litter production in a New Zealand lowland podocarp-ratabroadleaf forest. New Zealand Journal of Botany 13: 173-187.

Department of Lands and Survey 1979: New Zealand topographical map 1:50000 NZMS 260 sheet S14 Hamilton (1 st edition). Wellington, Department of Lands and Survey.

Duncan, M. J. 1992: Flow regimes of New Zealand rivers. In: Mosley, M. P. ed. Waters of New Zealand. Wellington, New Zealand Hydrological Society Incorporated. Pp. 13-27.

France, R. L. 1995: Source variability in $\mathrm{d}^{15} \mathrm{~N}$ of autotrophs as a potential aid in measuring allochthony in freshwaters. Ecography 18: 318 320.

France, R.; Culbert, H.; Freeborough, C.; Peters, R. 1997: Leaching and early mass loss of boreal leaves and wood in oligotrophic water. Hydrobiologia 345: 209-214.

Gessner, M. O. 1991: Differences in processing dynamics of fresh and dried leaf litter in a stream ecosystem. Freshwater Biology 26: 387-398.

Griffith, M. B.; Perry, S. A. 1994: Fungal biomass and leaf litter processing in streams of different water chemistry. Hydrobiologia 294: 51-61.

Handley, L. L.; Raven, J. A. 1992: The use of natural abundance of nitrogen isotopes in plant physiology and ecology. Plant, Cell, and Environment 15: 965-985.

Hanson, B. J.; Cummins, K. W.; Barnes, J. R.; Carter, M. W. 1984: Leaf litter processing in aquatic systems: a two variable model. Hydrobiologia 111: 21-29.

Hicks, B. J. 1990: The influence of geology and timber harvest on channel morphology and salmonid populations in Oregon Coast Range streams. Unpublished Doctoral thesis, Oregon State University, Corvallis, Oregon. $199 \mathrm{p}$.

Hicks, B. J. 1997: Food webs in forest and pasture streams in the Waikato region: a study based on analyses of stable isotopes of carbon and nitrogen, and fish . gut contents. New Zealand Journal of Marine and Freshwater Research 31: 651-664.

Irons, J. G.; Oswood, M. W.; Stout, R. J.; Pringle, C. M. 1994: Latitudinal patterns in leaf litter breakdown: is temperature really important? Freshwater Biology 32: 401-411.

Lester, P. J.; Mitchell, S. F.; Scott, D; Lyon, G. L. 1995: Utilisation of willow leaves, grass and periphyton by stream macroinvertebrates: a study using stable carbon isotopes. Archiv für Hydrobiologia 133: 149-159. 
Linklater, W. 1991: The riparian vegetation-stream macroinvertebrate relationship in small forest streams, Canterbury, New Zealand. Unpublished MSc thesis, University of Canterbury, Christchurch, New Zealand. 89 p.

Linklater, W. 1995: Breakdown and detritivore colonisation of leaves in three New Zealand streams. Hydrobiologia 306: 241-250.

Linklater, W.; Winterbourn, M. J. 1993: Life histories and production of two trichopteran shredders in New Zealand streams with different riparian vegetation. New Zealand Journal of Marine and Freshwater Research 27: 61-70.

Marchant, R.; Barmuta, L. A.; Chessman, B. C. 1995: Influence of samples quantification and taxonomic resolution on the ordination of macroinvertebrate communities from running waters in Victoria, Australia. Marine and Freshwater Research 46: 501-506.

Miller, R. B. 1963: Plant nutrients in hard beech. III. The cycle of nutrients. New Zealand Journal of Science 6: $388-413$.

Mulholland, P. J.; Elwood, J. W.; Webster, J. R.; Ferren, L. A.; Perkins, R. E. 1984: Phosphorus uptake by decomposing leaf detritus: effect of microbial biomass and activity. Vereinigung Internationale für Theoretische und Angewandte Limnologie Verhandlungen 22: 1899-1905.

Murphy, M. L.; Meehan, W. R. 1991: Stream ecosystems. Influences of forest and rangeland management on salmonid fishes and their habitats. American Fisheries Society Special Publication 19. Bethesda, Maryland. Pp.17-46.

Parkyn, S. M.; Winterbourn, M. J. 1997: Leaf breakdown and colonisation by invertebrates in a headwater stream: comparisons of native and introduced species. New Zealand Journal of Marine and Freshwater Research 31: 301-312.

Petersen, R. C.; Cummins, K. W. 1974: Leaf processing in a woodland stream. Freshwater Biology 4: 343-368.

Peterson, B. J.; Fry, B. 1987: Stable isotopes in ecosystem studies. Annual Review of Ecology and Systematics I8: 293-320.
Quinn, J. M.; Williamson, R. B.; Smith, R. K.; Vickers, M. L. 1992: Effects of riparian grazing and channelisation on streams in Southland, New Zealand. 2. Benthic invertebrates. New Zealand Journal of Marine and Freshwater Research 26: 259-273.

Sedell, J. R.; Triska, F. J.; Triska, N. S. 1975: The processing of conifer and hardwood leaves in two coniferous forest streams: I. Weight loss and associated invertebrates. Vereinigung Internationale für Theoretische und Angewandte Limnologie Verhandlungen 19: 1617-1628.

Short, R. A.; Canton, S. P.; Ward, J. V. 1980: Detrital processing and associated macroinvertebrates in a Colorado mountain stream. Ecology 61: 727732.

Sweetapple, P. J.; Fraser, K. W. 1992: Litterfall from a mixed red beech (Nothofagus fusca)-silver beech (Nothofagus menziesii) forest, central North Island, New Zealand. New Zealand Journal of Botany 30: 263-269.

Wilkinson, L. 1997: SYSTAT ${ }^{(\mathbb{R})} 7.0$ statistics. Chicago, SPSS Inc.

Triska, F. J.; Sedell, J. R.; Buckley, B. 1975: The processing of conifer and hardwood leaves in two coniferous forest streams: II. Biochemical and nutrient changes. Vereinigung Internationale für Theoretische und Angewandte Limnologie Verhandlungen 20: 1359-1365.

Webster, J. R.; Benfield, E. F. 1986: Vascular plant breakdown in freshwater ecosystems. Annual Review of Ecology and Systematics 17: 567-594.

Webster, J. R.; Covich, A. P.; Tank, J. L.; Crockett, T. V. 1994: Retention of coarse organic particles in streams in the southern Appalachian mountains. Journal of the North American Benthological Society 13: 140-150.

Winterbourn, M. J. 1982: The invertebrate fauna of a forest stream and its association with fine particulate matter. New Zealand Journal of $\mathrm{Ma}$ rine and Freshwater Research 16: 271-281.

Winterbourn, M. J.; Rounick, J. S.; Cowie, B. 1981: Are New Zealand stream ecosystems really different? New Zealand Journal of Marine and Freshwater Research 15: 321-328. 
Appendix 1 Leaf dry weights before and after incubation in the Mangaotama Stream, Waikato, New Zealand, for 28 days, mass-loss rates, and invertebrate weights. (DD, degree day; $t_{50}$, time for $50 \%$ mass loss.)

\begin{tabular}{|c|c|c|c|c|c|c|c|c|}
\hline \multirow[b]{2}{*}{ Tree species } & \multicolumn{2}{|c|}{ Leaf weight $(\mathrm{g})$} & \multicolumn{2}{|c|}{ Invertebrate abundance } & \multicolumn{4}{|c|}{ Mass-loss rate } \\
\hline & Start & End & number $\mathrm{g}^{-1}$ & $\mathrm{mg} \mathrm{g}^{-1}$ & $k$ day $^{-1}$ & $k \mathrm{DD}^{-1}$ & $t_{50}$ & $\mathrm{DD}_{50}$ \\
\hline Melicytus ramiflorus & 6.099 & 0.832 & 151.4 & 53.4 & 0.0711 & 0.00491 & 10 & 141 \\
\hline Melicytus ramiflorus & 6.228 & 1.721 & 52.9 & 51.5 & 0.0459 & 0.00317 & 15 & 219 \\
\hline Melicytus ramiflorus & 6.611 & 2.471 & 34.3 & 15.7 & 0.0351 & 0.00242 & 20 & 286 \\
\hline Betula pendula & 12.530 & 5.890 & 17.4 & 9.1 & 0.0270 & 0.00186 & 26 & 373 \\
\hline Betula pendula & 13.067 & 4.496 & 20.5 & 17.1 & 0.0381 & 0.00263 & 18 & 264 \\
\hline Alnus glutinosa & 7.598 & 3.959 & 30.4 & 17.3 & 0.0233 & 0.00161 & 30 & 432 \\
\hline Alnus glutinosa & 7.745 & 4.160 & 33.9 & 20.6 & 0.0222 & 0.00153 & 31 & 453 \\
\hline Alnus glutinosa & 7.930 & 4.608 & 44.5 & 21.7 & 0.0194 & 0.00134 & 36 & 518 \\
\hline Dacrycarpus dacrydioides & 14.874 & 10.043 & 14.6 & 9.2 & 0.0140 & 0.00097 & 49 & 717 \\
\hline Dacrycarpus dacrydioides & 13.668 & 7.804 & 12.2 & 3.5 & 0.0200 & 0.00138 & 35 & 502 \\
\hline Dacrycarpus dacrydioides & 15.815 & 10.699 & 14.6 & 9.2 & 0.0140 & 0.00096 & 50 & 720 \\
\hline Nothofagus menziesii & 8.739 & 6.071 & 51.7 & 36.1 & 0.0130 & 0.00090 & 53 & 773 \\
\hline Nothofagus menziesii & 8.353 & 6.637 & 21.1 & 12.8 & 0.0082 & 0.00057 & 84 & 1224 \\
\hline Nothofagus menziesii & 8.028 & 6.111 & 15.9 & 8.0 & 0.0097 & 0.00067 & 71 & 1031 \\
\hline Knightia excelsa & 10.775 & 9.304 & 5.6 & 6.7 & 0.0052 & 0.00036 & 132 & 1917 \\
\hline Knightia excelsa & 11.111 & 9.764 & 9.6 & 4.7 & 0.0046 & 0.00032 & 150 & 2178 \\
\hline Knightia excelsa & 10.943 & 9.902 & 11.4 & 6.9 & 0.0036 & 0.00025 & 194 & 2815 \\
\hline Beilschmiedia tawa & 6.038 & 5.324 & 28.2 & 11.2 & 0.0045 & 0.00031 & 154 & 2236 \\
\hline Beilschmiedia tawa & 6.772 & 6.152 & 12.3 & 5.1 & 0.0034 & 0.00024 & 202 & 2931 \\
\hline Beilschmiedia tawa & 6.311 & 5.801 & 15.0 & 6.2 & 0.0030 & 0.00021 & 230 & 3340 \\
\hline
\end{tabular}

